\title{
An HRM Framework for Manufacturing Companies of Bangladesh Mapping Employee Rights' Protocols and Grievance Management System
}

\author{
Tarnima Warda Andalib and Mohd. Ridzuan Darun \\ Faculty of Industrial Management, University of Malaysia Pahang, Malaysia; \\ tarnima.warda.andalib@gmail.com,mridzuand@ump.edu.my
}

\begin{abstract}
Objective: This paper aims to propose an Human Resource Management (HRM) framework for the manufacturing companies of Bangladesh where Grievance Management System (GMS) and Employee Rights (ERS) protocols are mapped. Methods and Analysis: Researchers collected data of twelve listed manufacturing companies of Bangladesh where every company has customized HRM policies and practices dealing with employees. Bangladesh govt. has Bangladesh Labour Law for all the companies of Bangladesh, declared in the guideline named Bangladesh Labour Act 2006, where employees' rights and related laws are clearly mentioned. Findings: Therefore, researchers developed a new HRM framework mapping new HRM components named 'Employee rights' and 'Grievance management system', which were always mentioned in separate guideline but never have been mapped in the framework before. Novelty / Improvement: Mapping the HRM framework with employees' rights protocols and grievances management system motivates the employees by fulfilling their rights and by considering their wellbeing.
\end{abstract}

Keywords: Employee Rights, Grievance Management, HRM Framework

\section{Introduction}

In almost all the manufacturing companies of Bangladesh, human resource management is observed as a significant practice. In this study, the researchers did twelve case studies and observed the HRM situation of these companies to develop a framework where employee rights are taken into account and employees' grievances are managed. Moreover, in this globalization era, where knowledge is overriding in ensuring employee's rights, these HRM policies and practices have become insufficient to support managers in their decision making to stay away from all sorts of employee rights' violations rather implement those extensively ${ }^{1}$. Hence, the notion of developing an HRM framework revolves around the degree of integration of the available HRM components along with the inclusion of employee rights and grievances management components in the framework, which eventually will make HRM as well as the organization more effective, stronger and flourished ${ }^{2}$. Therefore, the Bangladeshi manufacturing companies are brought under observation and multiple case studies with in-depth interview have been undertaken to understand the real scenario by collecting appropriate evidence to form and propose an HRM framework, highlighting the fact that there is considerable diversity in HRM practices. Therefore, the main objective of this study is to include 'Employee rights' and 'Grievance management system' in the proposed new HRM framework. Previously, this dimension of developing an HRM framework was not taken into account.

$\mathrm{In}^{3}$ it is strongly debated that HRM operates as a form of insidious 'control by compliance' that in a way emphasizes the need for employees' commitment and loyalty, for eventual mutuality, but in reality, reveals that behind the rhetoric it exploits the workers. This indicates that employees' rights are in some manner not fulfilled

*Author for correspondence 
rather exploited. The reason is that during the development of HRM policies, employees are considered as mere resources or a tool for production purposes but not as human beings even though remarked that the employees are the most important assets in an organization ${ }^{4}$. In a corporate context, an employee is a person who is hired to provide services to a company on a regular basis in exchange of compensation and who does not provide these services as part of an independent business ${ }^{5}$. According to Universal Declaration of Human Rights (UDHR) and its Article 23 (3), every worker has the right to a just and favorable remuneration, thereby ensuring an existence worthy of human dignity, and supplemented, if necessary, by other means of social protection ${ }^{6}$. International Labor Organization (ILO) also has developed certain protocols that specifically have defined and recognized different rights of an employee. These protocols are actually developed to protect the rights of the employees at the workplace, through the provision of work security as well as recognized the respect for the fundamental rights of human beings that indicates that employees are human beings, just not mere working tools ${ }^{7}$. The implication of this is that employees need not just to be controlled and maintained but also need to be nurtured.

\subsection{Background Incidents}

The following widely reported incidents are revealing the kind of violations regarding employee rights' protocols around the world. Such incidents have driven and given a strong foundation for this study. Incident One: T-Mobile Company, an American company declared that they want to stay union free because they believed supervision is the key' T-Mobile also opposed workers freedom of association by violating the ILO rules. Some of the employees protested and consequently, they were immediately relieved of their duties. The employees were not only sacked, they were also threatened to stay clear of any protest ${ }^{8}$. Incident Two: A German company, Deutsche Post established in 2001 declared a 'code of conduct' based on International agreement guidelines including UDHR, International Labour Organization, and The Global Compact. Interestingly, one of their employees Ms. Nilsa Rod Risuez told Human Rights Watch in an interview that 'Employees don't have any rights here because we can be fired at any moment for no reason. The supervisors insult and treat the employees badly. However, employees are afraid to file any 'Injury report' even if they are hurt because they do not wish to lose their jobs'. Incident Three: In Cosco shipping company Greece, they do not allow 'Labour Union' or 'Collective Bargaining. The workers are asked to take few minutes off only for taking food at around 12 p.m. and are restricted from toilet breaks. Rather, the employees are asked to urinate into the sea ${ }^{10}$. Incident Four: on 25th May 2014, Foxconn Technology Group was prosecuted by SACOM (Students and scholars' against corporate behavior) for an abnormal number of workers' suicides in Taiwan. One hundred and fifty (150) workers threatened to commit suicide on Jan 2012 due to adverse working condition ${ }^{11}$. Incident Five: In On 24th April 2013, Rana Plaza of Savar, Bangladesh collapsed and out of 2,500 people, 1,127 were reportedly killed. This happened even though the architects and engineers demanded that operations in the building be stopped immediately for safety purpose of the employees. The managers did not only continue the operations risking the 'employees' lives' and also forced some employees to come to work in a regular manner ${ }^{12}$.

All the above incidents have found two most important common factors that must be addressed in the HRM policies and practices, which are (i) the employees' rights and (i) the grievance management platform ${ }^{13}$. (i) Employees' rights: The above incidents indicate that employees are exploited and their rights violated in different ways. According to the Universal Declaration of Human Rights ${ }^{14}$ and its embedded articles regarding the right to life, liberty and security (no.3), freedom from slavery (no.4) and working in favorable conditions (no. 23) employee rights got violated severely in the above incidents ${ }^{15}$. (ii) Grievance management platform: Almost every grievance procedure provides for an informal or first step grievance meeting and every grievance that is lost because of time limits is a forfeiture of the rights that were hard-won on the battlefield of collective bargaining ${ }^{16}$. Claimed that an effective union representation avoids this needless tragedy by developing a redundant safeguard system ${ }^{16}$. Therefore, the incidents here disclosed that if a discussion platform can be built where the employer will satisfactorily explain the employees' complaints at an individual level, the grievance could be redressed, and actually, it will benefit the employer. 


\subsection{Employee Rights Standards' (UDHR, ILO, BDL)}

There are Universal standards where employee rights are significantly mentioned and nurtured, which are Universal Declaration of Human Rights ${ }^{14}$ and International Labour Organization (ILO). Bangladesh also has got Bangladesh Labour Law (BDL), which has been formed with the shadow of ILO mainly. Nevertheless, these standards have some basic protocols, which are significantly important for employee rights. These are Article ${ }^{3},{ }^{4,21,23}$ from UDHR and ILO standard there are several conventions regarding manufacturing industry. There are certain protocols to protect employees' Rights everywhere in the world. In this section, The Universal Declaration of Human Rights $^{14}$, The International Labor Office (ILO) protocols, conventions and articles and The Bangladesh Labour Law (BDL) are discussed and it is pointed out how these are related to the employees.

\subsubsection{Universal Declaration of Human Rights}

The universal declaration of human rights was adopted by the general assembly of the united nations on 10 December 1948. It was the first global expression of human rights ${ }^{17}$, which are basic to all human species. According to united nations, report udhr resulted directly from the experience of the second world war and represents the first global expression of the fundamental rights of human beings. The general assembly is the main deliberative body of the united nations which comprises all the member states. The assembly meets regularly in annual sessions under a president elected from among the member states ${ }^{15}$. One general assembly resolution consists of 'udhr' and two international treaties established by united nations under the rubric of the international bill of human rights. The two covenants were adopted in 1948, which are the international covenant on civil and political rights with its two optional protocols and the international covenant on economic, social and cultural rights ${ }^{15}$. The two covenants entered into force in 1976, after the ratification by the sufficient number of individual nations. This bill became a part of international $\mathrm{law}^{18}$. Udhr consists of 30 articles and is published by the united nations and has been elaborated in subsequent international treaties, regional human rights instruments, national constitutions, and laws ${ }^{19-20}$. Among all the under articles, three articles have highlighted employees' rights. Each article has specific areas where it has focused on certain employee rights. These articles help the organization to enrich their human resource management policy.

\subsubsection{Interational Labour Organizations (ILO)}

International Labour Organization has considerably declarations on legal and social issues regarding industrial development focusing on the humanitarian grounds. Shekhar mentioned in 2012 some major key points of ILO declarations that have protected the values of employee rights relating to employee responsibilities. There are a few ILO key points, which are Trade Union response, HRM, recruitment, and selection, factors influencing HR, industrial relations with HRM. He referred to 'Trade Union Response' relating to the threat of unemployment, redundancy, and problems of retraining, also discussing the major benefits of improved technology under modernization, negotiated change, appropriate training, accent on team work and supportive management practices. The second point is 'HRM practices' that motivate the employees in respect of their aggregated attributes, which are knowledge, skills, and experiences along with health conditions. Shekhar also claimed that HRM is a strategic management function that deals with the human resource aspect of corporate policy, formulation of human resource objectives, policies, procedures and programs for implementing these policies. The third point is concerned with 'Recruitment and selection' the necessary training of the new employees who can be motivated and developed as the human beings in an organization, by setting their grievances and, offering convenience which they deserve. These are the issues, which are addressed in ILO specifically. The fourth point of ILO relates to the 'Factors Influencing HRM', which are available and required manpower, nature, and type of employees, vocational and professional standards of manpower, the value system of the individual and their attitude, level of knowledge and skills, creativity and innovation of employees. The fifth and final point of ILO declaration concerns industrial relations and the way that HRM works in improving industrial relations. In this area, the HR managers must create a congenial climate so that employees commit themselves to work and can contribute to performing quality work.

The unique tripartite structure of the ILO gives an equal voice to workers, employers, and governments in order to ensure that the views of the social partners are closely reflected in labor standards and in shaping policies 
and programs. The ILO was founded in the wake of WWI, to pursue a vision based on the premise that a universal and lasting peace can be established only if it is based on social justice. The ILO became the first specialized agency of the UN in 1946. The ILO has certain protocols, which are designed to protect employee rights. These protocols have linkages and connections with many distinct conventions. These protocols are P155, P147, P110, P089, P081 and P029 etc 7 . Table 1 has described these in brief.

The ILO also has Protocols and Conventions which are designed to protect employees' rights in the manufacturing industries. These protocols and conventions have been created and ratified at different times. There are dedicated articles for each protocol and convention. For example, Discrimination (Employment and Occupation) is an ILO convention which is clearly described in the Articles 1 to 14 . Table 2 gives a glimpse of it.

\subsubsection{Bangladesh Labour Law (BDL)}

Bangladesh Labour Law (BDL) was enacted in 1997 and modified in 2006. The 2006 Act included ${ }^{25}$ important Labour Laws developed after prolonged tripartite negotiations. This law code more specifically introduced a number of items such as retirement benefit, enhancement of compensation for both death and permanent disability, the introduction of provident fund for workers, punishment for sexual harassment etc ${ }^{21}$. Bangladesh Employers' Federation, BEF was deeply involved in formulating the Bangladesh Labour Act 2006. BEF worked under the ILO umbrella during the formulation of the BDL and included

Table 1. Employee rights in UDHR article

\begin{tabular}{|c|c|c|}
\hline Article Number & Focused Employee Rights & Specific area of HRM policy \\
\hline \multirow{7}{*}{ Article 23} & Right to Work & Employment (Recruitment \& Selection) \\
\hline & Right to choose his/her work & $\begin{array}{l}\text { Remuneration } \\
\text { Compensation package }\end{array}$ \\
\hline & Right to stay employed in just and favorable condition & $\begin{array}{l}\text { Organization Environment } \\
\text { Organization Goal and Culture } \\
\text { Job Security }\end{array}$ \\
\hline & Right to get protection against unemployment & $\begin{array}{l}\text { Health Insurance } \\
\text { Medical Treatment } \\
\text { Social Help } \\
\text { Children protection } \\
\text { Protection against Accidents/ Incidences } \\
\text { Insurance } \\
\text { Provident Fund } \\
\text { Gratuity }\end{array}$ \\
\hline & Right to Equal Pay (No discrimination) & $\begin{array}{l}\text { Legal } \\
\text { Gratuity }\end{array}$ \\
\hline & $\begin{array}{l}\text { Right to stay dignified and right to get rights worthy of human } \\
\text { being }\end{array}$ & $\begin{array}{l}\text { Dignity } \\
\text { Health and Life Insurance }\end{array}$ \\
\hline & $\begin{array}{l}\text { Right to form /join trade unions for the protection of his/her } \\
\text { interests }\end{array}$ & Trade Union \\
\hline Article 24 & Right to Rest and Leisure & $\begin{array}{l}\text { Maternity Leave } \\
\text { Rest Hours }\end{array}$ \\
\hline \multirow[t]{2}{*}{ Article 25} & $\begin{array}{l}\text { Right to a standard of living adequate for the health and well } \\
\text { being of himself and of his family }\end{array}$ & $\begin{array}{l}\text { Health Insurance } \\
\text { Medical Treatment } \\
\text { Social Help } \\
\text { Children protection } \\
\text { Family Support facilities }\end{array}$ \\
\hline & $\begin{array}{l}\text { Right to special protection, assistance and care for motherhood } \\
\text { and childhood (born in or out of wedlock same social } \\
\text { protection) }\end{array}$ & $\begin{array}{l}\text { Maternity Leave } \\
\text { Maternity health insurance policies } \\
\text { Children protection } \\
\text { Dignity }\end{array}$ \\
\hline
\end{tabular}


Table 2. ILO Protocols and related conventions

\begin{tabular}{|l|l|}
\hline ILO Protocols & Related Conventions \\
\hline P155 (2002) & Protocol of 2002 to the Occupational Safety and Health Convention, 1981 \\
\hline P155 (2002) & Protocol of 2002 to the Occupational Safety and Health Convention, 1981 \\
\hline P147 (1996) & Protocol of 1996 to the merchant shipping (minimum standard) convention, 1976 \\
\hline P110 (1982) & Protocol of 1982 to the plantations convention, 1958 \\
\hline P089 (1948) & Protocol of 1999 to the night work (women) convention (revised), 1948 \\
\hline P081 (1999) & Protocol of 1995 to the labor inspection convention, 1947 \\
\hline P029 (2014) & Protocol of 2014 to the forced Labour convention, 1930 \\
\hline
\end{tabular}

Source: (ILO_Geneva_Rev, 2012)

a lot of protocols from ILO in it. Certain Protocols specified in this code and are obligatory and must be implemented by Bangladesh Local Governments.

\section{Methods and Materials (Sampling and Data Collection)}

The researcher used qualitative methodology with grounded theory and applied multiple case studies with in-depth description and analysis of the HRM activities supported by ${ }^{22}$. In this study, multiple cases are selected for the collection of data as these are more compelling and generate better-grounded theory than single cases ${ }^{23,1}$. In addition, multiple case studies provide a stronger base for the development of an HRM framework ${ }^{13,1,24}$. Multiple case studies were chosen because here, other than the background problem, nothing was known with regards to the situation with the exception of the Listed Bangladeshi manufacturing companies. These were used as the unit of analysis. This study has collected data from multiple bound systems over time through a detailed step-by-step process using multiple sources of information (observations, interviews, audiovisual materials, documents, and reports) and reported explanations of multiple cases and case-based themes $\mathrm{s}^{25,22}$.

The study replicates these methods for all the cases and identified common themes to do coding, thematic analysis; cross-case analysis for the development of the new HRM framework has affirmed that the multiple case studies utilize the logic of replication, where the procedures are replicated for each case. The multiple case studies approach follows an analytical strategy to identify issues; find and finalize the common themes ${ }^{26,24}$. This approach has a typical format for each case description called 'within case analysis' followed by a thematic analysis across the cases called a 'cross-case analysis', with assertions or interpretations of the meaning of each case and has quite a rich context ${ }^{25,6}$. Researchers used purposeful sampling and selected the participants' and the cases for the study. On the basis of participants' understanding of the central problem of the study, the central idea has been evolved ${ }^{25}$. Initially, the listed manufacturing companies were extracted from the stock markets of Bangladesh and then, based on four categories; the cases are selected. Researchers found that the Dhaka Base Stock exchange has got 146 listed manufacturing companies in Bangladesh. Then other sorting criteria were used to choose companies for this study. The criteria were; The Company Govt. Act 1994 with more than 500 employees and the use of heavy machinery in the company premises. Almost $99 \%$ cases from the list fall in this group by default. Table 3,4 details the criteria used to select the cases. All this information was collected from Dhaka Stock Exchange lists argued that the purposeful sampling can include events, settings, participants and artifacts' and can, during the study, be changed, giving the researcher some flexibility Twelve (12) cases were chosen. Collected data were recorded as voice records and transcribed into texts for further analysis.

\section{Results and Discussion}

In this study, the researchers observed the in-depth interviews and analyzed the transcriptions by NVIVO tool, did coding and formed open codes, categorized codes, themes and also did cross-case analysis of all the cases based on Employee Rights protocols and Grievance Management system components, since these two components are to be mapped to the newly developed HRM framework. By Following Miles and Huber man technique, Open codes 
Table 3. ILO conventions

\begin{tabular}{|c|c|c|c|}
\hline ILO Conventions & $\begin{array}{l}\text { Year } \\
\text { (Adopted) }\end{array}$ & $\begin{array}{l}\text { Year (Came } \\
\text { Into Force) }\end{array}$ & $\begin{array}{l}\text { Articles } \\
\text { (where } \\
\text { described) }\end{array}$ \\
\hline Freedom of Association \& Protection of the Right to Organize Convention 1948 (No. 87) & 9July1948 & 4July 1950 & 1 to 21 \\
\hline Right to Organize and Collective Bargaining Convention,1949 (No. 98) & 1July1949 & 18July1951 & 1 to 16 \\
\hline Forced Labour Convention, 1930 (No. 29) & 28June1930 & 1 May1932 & 1 to 33 \\
\hline Abolition of Forced Labour Convention, 1957 (No. 105) & 25June1957 & 17Jan1959 & 1 to 10 \\
\hline Minimum Age Convention, 1973 (No. 138) & 26June1973 & 19June1976 & 1 to 18 \\
\hline Worst Forms of Child Labour Convention, 1999 (No. 182) & 17June1999 & 19 Nov2000 & 1 to 16 \\
\hline Equal Remuneration Convention, 1951 (No. 100) & 29June1951 & 23May1953 & 1 to 14 \\
\hline Discrimination (Employment \& Occupation) Convention, 1958 (No. 111) & 25June1958 & 15June1960 & 1 to 14 \\
\hline
\end{tabular}

Source : (ILO_Geneva_Rev, 2012)

Table 4. Criteria to find cases (Purposeful Sampling)

\begin{tabular}{|l|l|l|l|}
\hline Serial & & Reasons & Reference \\
\hline 1 & Dhaka Base & Dhaka Stock exchange & http://www.dsebd.org/ \\
\hline 2 & $\begin{array}{l}\text { Following the } \\
\text { upgraded Company } \\
\text { Govt. Act 1994 }\end{array}$ & $\begin{array}{l}\text { Age, Public Listed Age (Bangladesh Company Act } \\
1996)\end{array}$ & $\mathrm{In}^{29}$ \\
\hline 3 & $\begin{array}{l}\text { Employee Numbers } \\
(>500)\end{array}$ & $\begin{array}{l}\text { If employee number }>200 \text { then is considered as } \\
\text { Category A (According to Govt.) }\end{array}$ & In $^{37}$ \\
\hline 4 & $\begin{array}{l}\text { Usage of Heavy } \\
\text { Machineries } \\
\text { (Manufacturing } \\
\text { Base ) }\end{array}$ & $\begin{array}{l}\text { Mixed Industries: Usage of Heavy Machineries } \\
\text { Technology. The companies where usage of heavy } \\
\text { machineries exist and many employees and labours } \\
\text { are working in there. (Listed companies) }\end{array}$ & $\begin{array}{l}\text { 1.https://fred.stlouisfed.org/series/ } \\
\text { DDOM01BDA644NWDB, } \\
\text { bangladesh/listed-domestic-companies- } \\
\text { total-wb-data.html }\end{array}$ \\
\hline
\end{tabular}

are formed from the quotes and then a group of similar open codes is grouped as categorized codes to give a common meaning. Then, these categorized codes are grouped as 'themes'. These themes then formed the components of HRM framework. As per Thematic analysis and cross-case analyses were then performed to come up with the HRM components Electronic Reservation Slip ('ERS protocols') and 'GMS'. Finally, researchers developed the HRM framework by mapping ERS protocols and GMS in it.

\subsection{Employee Rights' Protocols (ERS protocols)}

As discussed previously, there are employee rights' protocols declared in UDHR, ILO, and BDL. In this study, researchers observed few manufacturing companies of
Bangladesh, which have either included or not included these protocols in their companies' guidelines and practices. From the evidence, it have been observed that UDHR, ILO or BDL are rated with implemented $(+++)$, partially implemented $(++)$ and with not implemented $(+)$ in different cases. Based on these rating cases are either found as integrated, Hybrid or not integrated properly. From this study, it has been observed that cases 6 and 11 are only integrated whereas cases 1,5 and 12 are hybrid and other cases $2,3,4,7,8,9$ and 10 are not integrated properly. Table 5 shows the cross-case analysis based on Employee rights protocols' usage inside the company.

Table 5, ++ stands for 'highly implemented', + stands for 'partially implemented' for all sections of UDHR, ILO and BDL. Cases are distinguished as integrated, partially integrated or non-integrated. 
Table 5. Cross case analysis based on Employee Rights Protocols

\begin{tabular}{|c|c|c|c|c|}
\hline \multicolumn{5}{|c|}{ Component: Employee Rights Protocols } \\
\hline Themes & UDHR & ILO & BDL & \multirow{2}{*}{ Outcome } \\
\hline Categories & Articles & Conventions & Sections & \\
\hline \multirow[b]{2}{*}{ Case 1} & + & ++ & ++ & \multirow[b]{2}{*}{ Hybrid } \\
\hline & $\begin{array}{l}\text { Partially } \\
\text { Included }\end{array}$ & Included & Included & \\
\hline \multirow[b]{2}{*}{ Case 2} & + & + & + & \multirow{2}{*}{$\begin{array}{l}\text { Non } \\
\text { Integrated }\end{array}$} \\
\hline & $\begin{array}{l}\text { Partially } \\
\text { Included }\end{array}$ & $\begin{array}{l}\text { Partially } \\
\text { Included }\end{array}$ & $\begin{array}{l}\text { Partially } \\
\text { Included }\end{array}$ & \\
\hline \multirow[b]{2}{*}{ Case 3} & + & + & + & \multirow{2}{*}{$\begin{array}{l}\text { Non } \\
\text { Integrated }\end{array}$} \\
\hline & $\begin{array}{l}\text { Partially } \\
\text { Included }\end{array}$ & $\begin{array}{l}\text { Partially } \\
\text { Included }\end{array}$ & $\begin{array}{l}\text { Partially } \\
\text { Included }\end{array}$ & \\
\hline \multirow[b]{2}{*}{ Case 4} & + & + & + & \multirow{2}{*}{$\begin{array}{l}\text { Non } \\
\text { Integrated }\end{array}$} \\
\hline & $\begin{array}{l}\text { Partially } \\
\text { Included }\end{array}$ & $\begin{array}{l}\text { Partially } \\
\text { Included }\end{array}$ & $\begin{array}{l}\text { Partially } \\
\text { Included }\end{array}$ & \\
\hline \multirow[b]{2}{*}{ Case 5} & + & ++ & ++ & \multirow[b]{2}{*}{ Hybrid } \\
\hline & $\begin{array}{l}\text { Partially } \\
\text { Included }\end{array}$ & Included & Included & \\
\hline \multirow{2}{*}{ Case 6} & ++ & ++ & ++ & \multirow{2}{*}{ Integrated } \\
\hline & Included & Included & Included & \\
\hline \multirow[b]{2}{*}{ Case 7} & + & + & + & \multirow{2}{*}{$\begin{array}{l}\text { Non } \\
\text { Integrated }\end{array}$} \\
\hline & $\begin{array}{l}\text { Partially } \\
\text { Included }\end{array}$ & $\begin{array}{l}\text { Partially } \\
\text { Included }\end{array}$ & $\begin{array}{l}\text { Partially } \\
\text { Included }\end{array}$ & \\
\hline \multirow[b]{2}{*}{ Case 8} & + & + & + & \multirow{2}{*}{$\begin{array}{l}\text { Non } \\
\text { Integrated }\end{array}$} \\
\hline & $\begin{array}{l}\text { Partially } \\
\text { Included }\end{array}$ & $\begin{array}{l}\text { Partially } \\
\text { Included }\end{array}$ & $\begin{array}{l}\text { Partially } \\
\text { Included }\end{array}$ & \\
\hline \multirow[b]{2}{*}{ Case 9} & + & + & + & \multirow{2}{*}{$\begin{array}{l}\text { Non } \\
\text { Integrated }\end{array}$} \\
\hline & $\begin{array}{l}\text { Partially } \\
\text { Included }\end{array}$ & $\begin{array}{l}\text { Partially } \\
\text { Included }\end{array}$ & $\begin{array}{l}\text { Partially } \\
\text { Included }\end{array}$ & \\
\hline \multirow[b]{2}{*}{ Case 10} & + & + & + & \multirow{2}{*}{$\begin{array}{l}\text { Non } \\
\text { Integrated }\end{array}$} \\
\hline & $\begin{array}{l}\text { Partially } \\
\text { Included }\end{array}$ & $\begin{array}{l}\text { Partially } \\
\text { Included }\end{array}$ & $\begin{array}{l}\text { Partially } \\
\text { Included }\end{array}$ & \\
\hline \multirow{2}{*}{ Case 11} & ++ & ++ & ++ & \multirow{2}{*}{ Integrated } \\
\hline & Included & Included & Included & \\
\hline \multirow[b]{2}{*}{ Case 12} & ++ & ++ & ++ & \multirow[b]{2}{*}{ Hybrid } \\
\hline & Included & $\begin{array}{l}\text { Partially } \\
\text { Included }\end{array}$ & Included & \\
\hline
\end{tabular}

\subsubsection{UDHR}

As described above UDHR had three articles that define employee rights. These are Article no. 3: Everyone has the right to life, liberty, and security of person, Article no. 4:
No one shall be held in slavery or servitude; slavery and the slave trade shall be prohibited in all their forms and Article no. 23: (1) Everyone has the right to work, to free choice of employment, to just and favourable conditions of work and to protection against unemployment; (2) Everyone, without any discrimination, has the right to equal pay for equal work; (3) Everyone who works has the right to the just and favourable remuneration ensuring for himself and his family an existence worthy of human dignity, and to be supplemented, if necessary, by other means of social protection; (4) Everyone has the right to form and to join trade unions for the protection of his interests ${ }^{4}$.

Included: From the evidence, cases 6,11 and 12 were found integrated fully. Talent management manager from case 6 said, "We implement employees' rights values and of course we are driven by UDHR guideline on this matter."

Partially included: From evidence, cases 1, 2, 3, 4, 5, 7, 8, 9 and 10 were found partially included UDHR. The assistant HR manager from case 2 said, "We do not follow UDHR protocols separately but I think it is automatically included in BDL which we do follow which are needed."Also, he added in case 2 "Ya, we accept that employees are human beings but in professional business, we have to act like professionals"

\subsubsection{ILO Protocols}

The ILO had certain protocols designed to protect employee rights, with connections with many distinct conventions. These protocols were P155, P147, P110, P089, P081 and P029 etc ${ }^{27}$. The ILO had particular protocols and conventions, created and ratified at different times, which were designed to protect the employees' rights in the manufacturing industry. All these protocols and conventions were thoroughly described in the Articles of UDHR and ILO. For example, discrimination (Employment and Occupation) is an ILO convention which is clearly prescribed in the Articles 1 to 14 .

Included: From evidence of this research, cases 1, 5 and 11 were seen to have ILO inclusion. HR executive from case 1 said, "We have Trade Unions for our factory labors" The statement mentions that to protect employees' rights unions are introduced to different manufacturing organizations in Bangladesh. Similarly, corporate affairs executive from case 3 said, "Certain rules that we have I think it has been taken from ILO." 
Partially included: Cases 2, 3, 4, 7, 8, 9, 10 and 12 had partially included ILO. HR head from case 8 said, "We follow Bangladesh Labour Code, it is a shadow of ILO." From case 8 , the factory supervisor said, "We have SOP guideline which we follow. SOP guideline may have ILO influences."

\subsubsection{BD Labour Act, 2006}

Bangladesh Labour Act $^{28}$ was promulgated on 11th October'2006. This Act specifically introduced 25 important labor laws after prolonged tripartite negotiation. The negotiations addressed issues like retirement benefit, enrichment of compensation for both death and permanent disability, the introduction of provident fund for workers, chastisement for sexual harassment and others ${ }^{21}$. The BEF documentation acknowledged the support of ILO for technical assistance while forming the labor law handbook. The 25 labor laws in BEF had consolidated legislations and provisions from the earlier 50 labor laws, which were applicable in Bangladesh. The Act was enacted by the Parliament with a provision for an authentic English text handbook according to Section 354 of the Bangladesh Constitution. Bangladesh Labour Law Act 2006 was designed in such a way that each important arena was focused in separate sections.

Included: From the evidence, cases 1, 5, 6, 11 and 12 had included BDL sections. In case ${ }^{11}$ the managing director said, "Of course we have to follow - we are under govt. haha." The Factory Head also in case 11 said, "Yes, our labors are satisfied with the BDL code and training of awareness regarding BDL is also given to them."

Partially included: From evidence cases 2, 3, 4, 7, 8, 9 and 10 had partially included BDL. Assistant HR manager from case 2 said, "It is mentioned in Bangladesh Labour Law. We follow BD Labour Law only... But, BDL might have taken the assistance of ILO mentioned by BEF". In case 2 he also added, "Participation is there. We declare Profit and the net profit's $5 \%$ will be allocated for the employees as per BD Labour Law Company bonus related guideline has been provided in Bangladesh Promo Odhidoptor this is customized but we need to take approval from Shromo Odhidoptor and there is a Factory wing which is called 'Kolkarkhana o protistan odidoptor".

\subsection{Grievance Management System (GMS)}

On the other hand, researchers also observed these manufacturing companies based on Turnover, Absenteeism and Visible expression of grievances, which signifies the grievance management system in those companies. These three themes are rated as High $(++)$ or Low $(+)$. The outcome of the cases are either active, hybrid or inactive. In this study, cases 1, 5 and 11 are active; cases 2, 3, 7, 8, 9 and 10 are inactive and cases 4 and 12 are hybrid cases.

\subsubsection{Turnover}

Research results show that employees' turnover intention has a negative correlation with industrial relations also that it negatively moderates the relationship between occupational commitment and industrial relations ${ }^{29}$. Lacking in Performance pay \& Employee Benefits: Despite the vast literature on both employee turnover and the impact of Performance-Related Pay (PRP) very few studies have investigated how employee turnover is affected by other PRP schemes, to the exclusion of profit sharing. Prior research suggests that workers receiving individual PRP and profit sharing are more satisfied with their jobs than those receiving pay based on traditional time-rates, even after accounting for the higher pay levels associated with $\mathrm{PRP}^{30}$. Consequently, if PRP workers are more satisfied with their jobs, they may experience lower turnover than traditional time-rate workers as mentioned by, making a better result than other workers on profit sharing apply more broadly to all workers receiving $\mathrm{PRP}^{31}$. Lacking in Corporate Ethics: Strong positive relation has been found between corporate ethical values with turnover ${ }^{32}$.

Strongly existent: It is shown that in cases $2,3,4,7,8$, 9 and 12 have strongly extent turnover. In case 7 the HR manager said, "We are still developing our HRM policy so due to payment issue employees leave every year." A participant one in case 7 said, "There are also many other opportunities missing so often employees feel deprived and leave."

Similarly, in case 2 the assistant HR manager said, "We see employees leaving when they get a higher salary in any other company." Also in case, 2 participants two said, "In every company, it happens employees may leave because of their discomforts."

Similarly, in case 9 the factory head said, "Labours from the factories often leave because it is a lot of hard 
work. Also in case 9, an engineer in the factory said, "We have lots of primitive machinery and lots of manual works to be done, sometimes employees get seriously ill and they leave the job."

Weakly existent: Evidence shows that cases 1, 5, 6, 10 and 11 have a weakly existent turnover. In case 1 the MD of the HR department said, "It is rare for employees to leave because we have a big brand name but we still see higher officials leaving because might be they are offered higher positions or much higher salary" Also in case 1 the assistant HR manager said, "Sometimes, employees leave because they go abroad for higher study"

In case 11 the HR manager said, "It is extremely rare to see any employee leaving the job because we are govt. Run Company and after retirement, there is a huge pension scheme." Also in case 11, an HR executive said, "Because of a govt. the agency we have many facilities that are not observed that much in real life."

\subsubsection{Absenteeism}

Organizations' employees can be frustrated for various reasons related to their company at work. However, it is very important to identify the employees going through these frustrations and try to guide them or to discuss the problem openly instead of being silently frustrated. These can be identified as employees being absent for days, taking frequent leaves or often arriving late at the office and leave early. In this situation, employees do not appear to care about the targets set by the organization. The three identified categorized codes of turnover are: Leave of Absence, Not meeting work targets and Late Arrival.

Strongly existent: Evidence shows that cases 2, 3, 7, 8 and 9 have strongly existent absenteeism. In case 7 participants one said, "Sometimes when employees are very much frustrated they often take sick leaves". In case 7 participants one said, "We find some of the employees always not serious about their work."

In case 3 the head of HR said, "You know because the employees know their jobs won't be gone sometimes they are very callous and late at work." In case 8 Union Leader five added, "Yes, this is true, because we cannot terminate someone so directly, there is a long process of termination so employees sometimes take that chance".

In case 8 the HR manager said, "Sometimes, we find employees who do not complete their targets and also quite reluctant about meeting the targets." An HR manager from case 8 added, "We arrange counseling sessions with the employees individually to understand what is wrong with them ..."

Weakly existent: Evidence shows that case 1, 4, 5, 6, 10, 11 and 12 have weakly existent absenteeism. The general manager in case 4 said, "We try to check always who are regular and who are irregular at the office to understand the intention and motivation level of the employees." In case 4 the HR manager said, "Only if the reason of absence is something really serious like a health problem or family issues then we do not consider that as a serious problem for the organization..."

Similarly, in case 6, the HR director said, "Sometimes, we find some of the employees are always late for office... so this is a serious concern for us as well.... In case 6, the HR manager said, "We are thinking of introducing counseling sessions properly for the employees."

\subsubsection{Visible Expression of Grievance}

When an employee or a group of employees of the organization decide to confront the management of the organization with complaints, protests and claims, the clear expression of grievances are revealed. Nevertheless, this only happens where the organization has not met the necessary needs of the employees for quite a long period of time.

In 2004, Brian stated that grievances are defined as disputes that arise between an employer and employee due to an employment agreement and goes on to state that grievances usually depend on 'causes' or 'reasons' that validates these ${ }^{33}$. Historically employees' grievances were handled by penalizing the employees through warnings, suspensions, and discharges (BNA Editorial Staff, 1959-1987:11). However, Cleyman argued in 1995 that grievances can be handled by developing a healthy relationship between the employer and the employees since observation has shown that employees who perceived a high-quality information exchange relationship with their supervisors would be less likely to file grievances than employees who perceived a low-quality information exchange relationship ${ }^{34}$

Protests: Since 2011, a "new global cycle of protests" has developed in Bangladesh, characterized by public expressions of outrage, fury, and resentment ${ }^{35}$. 
File Complaints: Employees when faced with such adverse situations inside the organizations firstly express, and then file complaints and then protest against the management ${ }^{35}$. Suppression of Employee Union: The findings demonstrate that the degree of direct control over the formal voice of the trade union leaders is minimal; suppressed voices are less heard. The loss of workers' control over the labor process has led to decreasing informal voice at the individual level. However, the earlier argument on workers' patience is not supported due to a growing number of organized workers protests ${ }^{36}$.

Strongly existent: Evidence shows that cases 2, 3, 7, 8 and 9 have a strongly existing visible expression of grievances. The head of the factory in case 8 said, "Labours complain when SOP's are not working properly. All steps regarding factory are mentioned in SOP. However, we are trying hard to resolute all conflicts through more effective SOP." In case 8, one of the union leaders said, "Well, if our workers have any problem may come to us for the resolution and we try to solve it among ourselves without disturbing the management all the time."

Similarly, in case 7, participant one said, "Labours have demands sometimes it becomes not possible for the management to fulfill so they try to protest." In case 7, a union leader said, "Many times we have a complaint about many necessities like regarding drinking water, latrines, food canteen, medical facilities and once we had to protest for a claim for one of our fellow workers' accident case."

The assistant manager in case 2 said, "We do have some issues at the worker level but that is not serious.

Table 6. Cross case analysis based on Grievance Management System

\begin{tabular}{|c|c|c|c|c|c|c|c|c|c|}
\hline \multicolumn{10}{|c|}{ Component Grievance Management System } \\
\hline \multirow{2}{*}{$\begin{array}{l}\text { Themes } \\
\text { Categories }\end{array}$} & \multicolumn{2}{|c|}{ Turnover } & \multicolumn{3}{|c|}{ Absenteeism } & \multicolumn{3}{|c|}{ Visible Expression of Grievances } & \multirow{2}{*}{ Outcome } \\
\hline & LEPB & LCE & LoA & nMT & LA & $\mathrm{PR}$ & $\mathrm{FC}$ & SEU & \\
\hline \multirow{2}{*}{ Case 1} & + & + & + & + & + & + & + & + & \multirow{2}{*}{ Active } \\
\hline & \multicolumn{2}{|c|}{ Weakly Existent } & \multicolumn{3}{|c|}{ Weakly Existent } & \multicolumn{3}{|c|}{ Weakly Existent } & \\
\hline \multirow{2}{*}{ Case 2} & ++ & ++ & ++ & ++ & ++ & ++ & ++ & ++ & \multirow{2}{*}{ Inactive } \\
\hline & \multicolumn{2}{|c|}{ Strongly Existent } & \multicolumn{3}{|c|}{ Strongly Existent } & \multicolumn{3}{|c|}{ Strongly Existent } & \\
\hline \multirow{2}{*}{ Case 3} & ++ & ++ & ++ & ++ & ++ & ++ & ++ & ++ & \multirow{2}{*}{ Inactive } \\
\hline & \multicolumn{2}{|c|}{ Strongly Existent } & \multicolumn{3}{|c|}{ Strongly Existent } & \multicolumn{3}{|c|}{ Strongly Existent } & \\
\hline \multirow{2}{*}{ Case 4} & ++ & ++ & + & + & + & + & + & + & \multirow{2}{*}{ Hybrid } \\
\hline & \multicolumn{2}{|c|}{ Strongly Existent } & \multicolumn{3}{|c|}{ Weakly Existent } & \multicolumn{3}{|c|}{ Weakly Existent } & \\
\hline \multirow{2}{*}{ Case 5} & + & + & + & + & + & + & + & + & \multirow{2}{*}{ Active } \\
\hline & \multicolumn{2}{|c|}{ Weakly Existent } & \multicolumn{3}{|c|}{ Weakly Existent } & \multicolumn{3}{|c|}{ Weakly Existent } & \\
\hline & + & + & + & + & + & + & + & + & \\
\hline Case 6 & Weakl & & Weak & cistent & & Wea & isten & & Active \\
\hline Cose 7 & ++ & ++ & ++ & ++ & ++ & ++ & ++ & ++ & Inactive \\
\hline Case / & Strong & & Stron & xisten & & Stro & xiste & & inactive \\
\hline$C_{0} e_{0}$ & ++ & ++ & ++ & ++ & ++ & ++ & ++ & ++ & Inostive \\
\hline Case 8 & Strong & & Stron & xisten & & Stro & xiste & & inactive \\
\hline$C_{3}{ }_{0}$ & ++ & ++ & ++ & ++ & ++ & ++ & ++ & ++ & Inoctive \\
\hline Case 9 & Strong & & Stron & xisten & & Stro & xiste & & Inactive \\
\hline & + & + & + & + & + & + & + & + & \\
\hline Case 10 & Weakl & & Weak & cistent & & Wea & isten & & Inactive \\
\hline Cree 11 & + & + & + & + & + & + & + & + & Active \\
\hline Case 11 & Weakl & & Weak & istent & & Wea & isten & & Active \\
\hline Cace 12 & ++ & ++ & + & + & + & + & + & + & Hyhrid \\
\hline Case 12 & Strong & & Weak & cistent & & Wea & isten & & Hybrid \\
\hline
\end{tabular}


However, my phone number is given to them, anyone may call me directly and other than that they can send messages or their complaints and within 24 hours we take action and resolve the issue...." Participant two in case 2 said, "Only once the labors locked down our factory due to some machinery problems."

Weakly existent: The study indicates that cases $1,4,5$, 10, 11 and 12 have weakly existing visible expression of grievances. In case 1 the HR director said, "We do pamper our employees with benefits and with good relationships so there are fewer possibilities of chaos." The MD in case 1 said, "We do not have such chaos but also you cannot make everyone happy so we accept written complaints sometimes from the employees." Table 6 shows the crosscase analysis based on Grievance Management System implementation inside the company.

In Table 6, Lacking in performance pay \& in Employee benefits stands for $=$ LEPB, Lacking in Corporate Ethics stands for $=\mathrm{LCE}$, Leave of absence stands for $=$ LoA, Not meeting the targets stands for nMT, Late Arrival stands for LA, Protests stand for = 'PR', File Complaints Stand for $=$ FC, Suppression of employee union stands for $=$ SoEU . Here, ' $++=$ stands for 'High', ' $+=$ stands for 'low'. In this table, Grievances Handling System for each case has been measured as Active, Partially Active or Inactive.

\subsection{The New HRM Framework}

Researchers have proposed a new HRM framework mapping the employee rights protocols and grievance management system for the manufacturing companies of Bangladesh. Figure 1 reveals the high-level drawing of the framework, where Grievance Management System and Employees' Rights Protocols components will exist besides other components of HRM framework like Organization culture, Recruitment, and Selection,

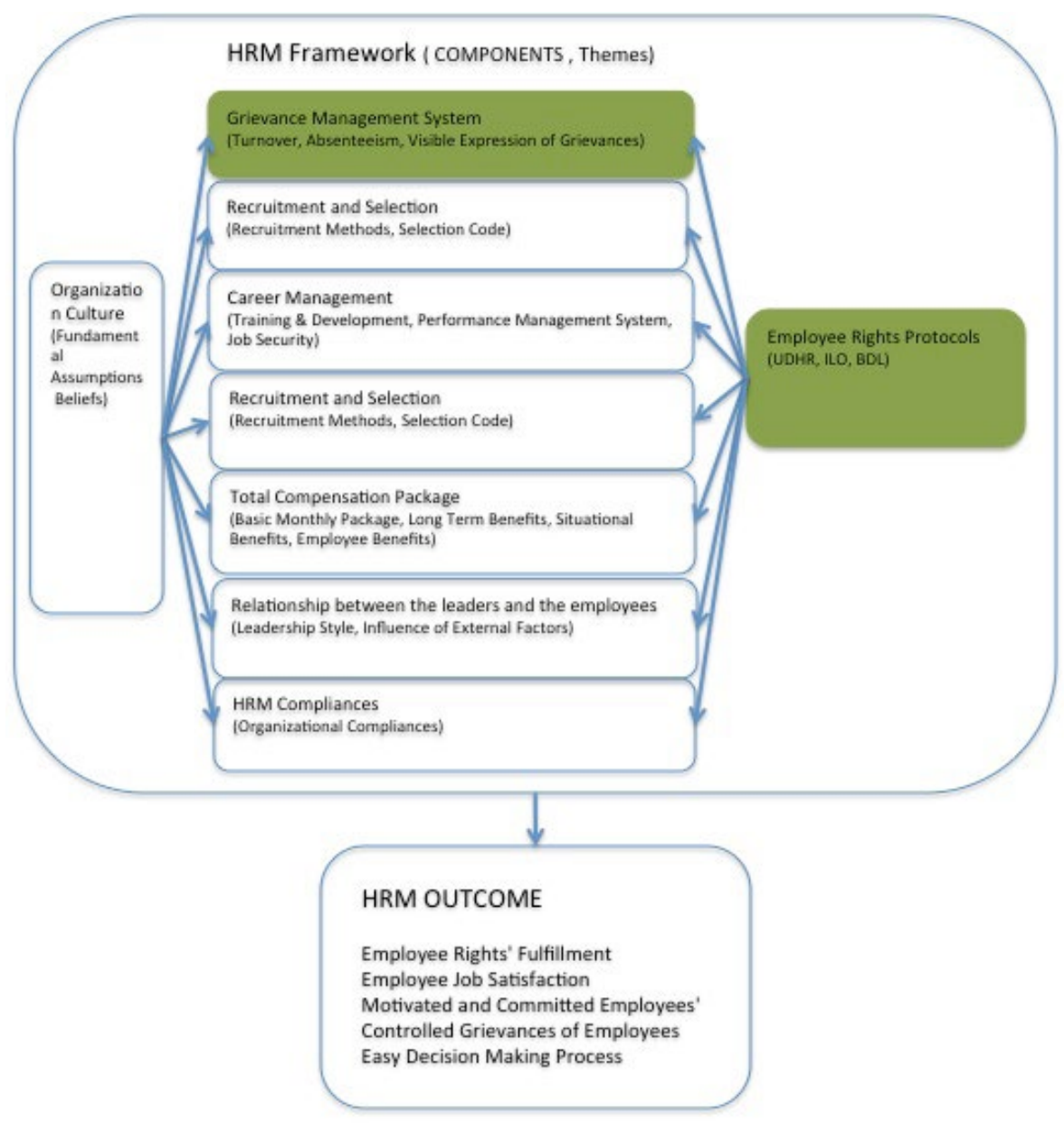

Figure 1. New HRM framework. 
Total Compensation Package, Relationship between the Leaders and the employees and HRM Compliances. In this framework, Organization culture and Employee Rights' protocols are independent variables and others are dependent variables. The following Figure 1 reveals the high-level drawing of the HRM framework.

\section{Conclusion}

The researchers gave heart and soul into this study knowing that there would be lots of hurdles, obstacles in this sensitive topic. It was clear that penetrating into the Bangladeshi manufacturing companies and collecting data would be a huge challenge. This journey was difficult and sometimes heart breaking but indeed challenging and interesting. In the proposed HRM framework, components like employee rights' protocols and grievance management system are mapped. This mapping means converging the other components of HRM framework with the themes named ILO, UDHR, and BDL, Turnover, Absenteeism and visible expression of grievances. In most of the previously developed HRM frameworks, the protocols and grievance control issues have been separately addressed in separate guidelines unlike mapping those in the HRM framework directly. Future researchers can extend this research and do the followings as well:

- Examine the changes of organizations based on the HRM framework with the effect of before and after mapping of two components (ERS protocols and GMS) directly. This might contribute to the body of HRM knowledge by informing leaders of the organizations, managers and scholars about HRM frameworks over time;

- Identify specific employee rights' violating factors that can adopt new HRM components to reduce stress. This could inform the practitioners and scholars to pay greater attention on those critical factors for mitigating the tension;

- Create a continuous effort to let employee rights dominate in the HRM frameworks;

- Create a single platform or base for HRM around the world because human beings have equal rights around the world no matter from which race, religion, gender, color, ethnicity group humans belong to.

\section{Acknowledgement}

Researchers heart-fully acknowledge the support of the HR department and employees of twelve manufacturing companies of Bangladesh for sharing information to use in this study.

\section{References}

1. Shore LM, Goldberg CB. Age discrimination in the workplace. In R. L. Dipboye and A. Colella (eds), Discrimination at Work: The Psychological and Organizational Bases. 2005; p.203-26.

2. Latham GP. A speculative perspective on the transfer of behavioural science findings to the workplace: the times they are a changing. Academy of Management Journal. 2007; 50(5):1027-32. crossref

3. Willmott H. Strength is ignorance, slavery is freedomL managing culture in modern organizations. Journal of Management Studies.1993; 30(4):551-2. crossref

4. Khatri N, Budhwar P, Fern CT. Employee turnover: bad attitude or poor management? 1999; p.1-42.

5. Cardy RL, Gove S, Dematteo J. Dynamic and customeroriented workplaces Implications for HRM practice and research. Journal of Quality Management. 2000; 5:159-86. crossref

6. Merriam SB. Theory to Practice : What can you tell from an $\mathrm{N}$ of 1 ? : Issues of validity and reliability in qualitative research. PAACE Journal of Lifelong Learning.1995; 4: 51-60.

7. International Labour Standards Department. Handbook of procedures relating to international labour Conventions and Recommendations. 2012; p.1-78.

8. T-mobile. Request for Investigation of T-Mobile US, Inc. 2015; p.1-12.

9. Compa LA, Feinstein F. Enforcing European Corporate Commitments to Freedom of Association by Legal and Industrial Action in the United States: Enforcement by Industrial Action. Cornell University ILR School. 2012; p.1-33.

10. Vassilopoulos J. Doc workers at piraeus Port, Greece end strike. World Socialist web site. 2014.

11. SACOM. iSlave Behind the iPhone Foxconn Workers in Central China. Students and Scholars against Corporate Misbehaviour. 2011; p.1-3.

12. McCavish P. Rana Plaza: A disaster from which we learn boxwood- works where it matters. 2012.

13. Demo G, Neiva ER, Nunes I, Rozzett K. Human Resources Management Policies and Practices Scale (HRMPPS): 
Exploratory and Confirmatory Factor Analysis. Paper presented at the BAR, Rio De janerio. 2012; 9(4):395-420.

14. UDHR. The United Nations. United for Human Rights. 1945.

15. United_Nations. Universal Declaration of Human Rights. 1945.

16. Fitzpatrick JKD. Effective-Grievance-Handling. Labor Management Conference. Jekyll Island, Georgia. 2006; p.1-18.

17. The International Bill of Human Rights. Universal Declaration Of Human Rights (art. 1). 1948; p.1-10.

18. Williams P. The International bill of human rights. United Nations, General Assembly: Entwhistle Books.1981; p.1-108.

19. Universal Declaration of Human Rights. 1948. 2011 August 19. Available from: https://www.humanrights.ch/en/standards/udhr/.

20. General Assembly of the United Nations. The 70th ordinary session opened. 2015.

21. A Handbook on the Bangladesh Labour Act 2006. International Labour Organization (ILO) LibraryBangladesh Employers' Federation. 2009.

22. Stake R. Data Gathering. The art of case study research. Thousand Oaks, CA: Sage. 1995; p.49-68.

23. Darun MR. The determinants of working capital management practices: A Malaysian perspective. Lincoln University, Christchurch- Newzealand. 2011; pp. 1-190.

24. Yin RK.Case study research design and methods. 4th Edition. Sage publications. 2009; p.1-240. PMCid:PMC2893845

25. Creswell JW. Research Design_ Qualitative, Quantitative, and Mixed Methods Approaches. 2nd Edition. London: SAGE Publications. 2013; p.1-26.

26. Eisenhardt KM, Eisenhardt K. building theories from case study research. The Academy of Management Review. 1989; 14(4):523-50. crossref crossref
27. Akhtaruddin M. Corporate mandatory disclosure practices in Bangladesh. The International Journal of Accounting. Elsevier. 2005; 40(4):399-422.

28. Eisenhardt KM, Graebner ME. Theory building from cases : opportunities and challenges. Academy of Management Journal, 2007; 50(1):25-32. crossref

29. The Bangladesh Labour Act 2006. 2015; p.1-179.

30. Yuan L, Yu Y, Li J, Ning L. Occupational commitment, industrial relations and turnover intention: Empirical evidence from China. Chinese Management Studies. 2014; 8(1):66-84. crossref

31. Heywood JS, Wei X. Performance pay and job satisfaction. Journal of Industrial relations. 2006; 48(4):523-40. crossref

32. O'Halloran PL. Performance pay and employee turnover. Journal of Economic Studies. 2012; 39:653-74. crossref

33. Kaur J, Sharma SK. Examining relationships among corporate ethical values, commitment and turnover intentions. South Asian Journal of Global Business Research. 2016; 5(1):32-52. crossref

34. Brian SH, Kleiner H. Effective grievance handling procedures. Management Research News. 2004; 27(1/2):85-94. crossref

35. Cleyman KL, Jex SM, Love KG. Employee Grievances : An Application of the leader-member exchange model. The International Journal of Organizational Analysis. 1995; 3(2):156-74. crossref

36. Hallberg D, Ossewaarde M. Protest and Recognition in the Bulgarian Summer 2013 Movement. New Perspectives (Research in Social Movements, Conflicts and Change, Emerald Group Publishing Limited. 2016; 39: 85-106.

37. Danilovich H. Struggling to Be Heard: The Past and Present of Employee Voice in Belarus. Employee Voice in Emerging Economies, Emerald Group Publishing Limited. 2016; 23:105-35. 